\title{
The contribution of student's perception on majors toward student's career planning
}

\author{
Ahmad Syaf Ya Habibi ${ }^{1}$, Neviyarni Neviyarni ${ }^{2}$, Marjohan Marjohan ${ }^{3}$ \\ ${ }^{123}$ Universitas Negeri Padang, Padang, - Indonesia, (habibidoang91@gmail.com)
}

\begin{abstract}
Career planning is important in the career development of students. Students in achieving careers often experience obstacles, for it takes an effort to overcome them. Student's perceptions on Majors are the factor that allegedly affects student's career planning. This study aims to describe the contribution of student's perceptions on majors toward student's career planning. This research used a quantitative approach with a correlational descriptive method. The population was 380 and the sample was 195 students. The instrument about student's perception on majors and student's career planning used Likert scale model with reliability 0.957. Data were analyzed using simple regression technique. The result shows that student's perception on majors was positive and student's career planning in the high category. There is a contribution (33.6\%) of student's perception on majors towards student's career planning.
\end{abstract}

Keywords: perception, majors, career planning.

\section{Introduction}

Career is important in human life, especially at the stage of adolescence. Teens need to be prepared and given a briefing to plan the career. Career planning should be done by someone as early as possible in order to frame a career that hard and strong to support a better future. Some businesses and activities that can be done teenagers, especially students in career planning is a way to learn and find out about careers, talk and discuss with adults about career plan, adhering to a course that helps students determine career, participated in the event job training (Sharf, 2010).

Students are expected to be able to plan careers in order to determine what steps will be done in the future. Planning a good career can be called also with careful planning and demanding students' thinking about all the goals to be achieved in the long term(long-range goals) and in the short term(short-range goals) (Winkel \& Hastuti,2013). The fact that a lot of students who do not have the ability to plan a career well, less interested in the subject that occupied at this time and did not have enough information about the world of work.

Erezka research results (2012) describe the general level career planning class XI SMA Kartika 1-5 Padang middle category. Further research conducted by the Princess, Neviyarni \& Irianto (2015) that Tool Reveals Common Problems (General AUM) were given to 29 students of class X SMK Nusatama Hospitality 2 Padang on September 10, 2014. A number of problems faced by students are a problem 
in the field of career and work with the problem components of $33.56 \%$ and total problems of $13: 46 \%$. Of the 29 students who fill the General AUM, as many as 12 students have problems in the item "Not knowing oneself talent for any job" and "Less has a broad knowledge of the ins and outs of employment and job types.

Students' progress in achieving the desired career is often challenging, so the need for efforts to overcome all these obstacles. Each student has different abilities to overcome obstacles that arise, so students need to prepare themselves for career planning.

Career planning of students in it there is also the role of perception as a powerful predictor associated with career planning students at the school. Perception is a process that involves the inclusion of an information into someone's mind. Through perception, the human constant contact with the environment (Khadijah, Marjohan \& Bentri, 2016).

Students who have a positive perception then make the best use of the opportunities that exist in the department occupied, according to the deliberations, so that later the students feel happy, comfortable and be professional in running. Conversely, if students have a negative perception of the department that is occupied will affect less good also in career development. This occurs because of a perception that does not fit on something that will affect the attitude and effort of students in the course of his career process, in other words, students undergo a half-hearted activity. This is consistent with research Lwin, Aslam \& Mukhale (2017) students' perceptions of their learning environment also affects the learning process.

Furthermore, research Kemboi, Kindiki \& Misigo (2016) to 347 students at the University Moi in Kenya showed that 203 students agree with their majors and after undergoing a learning process in the department they are satisfied, then 74 students do not agree with their majors and there is not satisfied with the department, then 51 students do not agree with their majors but after they undergo the activities permbelajaran in the department they are satisfied, then 19 students agreed with the department in which they live but they are not satisfied with the department occupied the.

It could be said that the perception of students about majors is one factor that has contributed to the students' career planning.

\section{Methods}

This study used a descriptive quantitative approaches-correlational. The study population 380, and a sample of 195 students. The instrument used was a Likert scale model. Data were analyzed using simple regression techniques.

\section{Results and Discussion}

The data in this study include the variable students' perception on majorsto the student's career planning.

1. Student's Perceptions on Majors, The following description of the proposed research data:

Table 1. The Student's Perception on Majors

\begin{tabular}{cccc}
\hline Interval Score & Category & F & \% \\
\hline $\mathbf{1 4 8 - 1 7 5}$ & Very Positive & 13 & 6.66 \\
$\mathbf{1 2 0 - 1 4 7}$ & Positive & 154 & 78.97 \\
$\mathbf{9 2 - 1 1 9}$ & Positive Enough & 28 & $14: 36$ \\
$\mathbf{6 4 - 9 1}$ & Negative & 0 & 0 \\
$\mathbf{3 5 - 6 3}$ & Strongly Negative & 0 & 0 \\
& Total & $\mathbf{1 9 5}$ & $\mathbf{1 0 0}$ \\
\hline
\end{tabular}


Table 1 shows as much as $6.66 \%$ of the students have a very positive outlook, $78.97 \%$ of students have a positive outlook and 14:36\% of students had a positive enough about the majors they are now, and there is no at all students who have a negative outlook and strongly negative especially against the majors that they occupy now. This means that the overall percentage of students' perceptions of the majors are in a positive category. Programs currently occupied by students is an option that has been planned by the student and the student also enjoys majors they have occupied it.

\section{Career Planning, The following description of the proposed research data}

Table 2. The Student's Career Planning

\begin{tabular}{cccc}
\hline Interval Score & Category & $\mathbf{F}$ & $\mathbf{\%}$ \\
\hline $\mathbf{1 4 0 - 1 6 5}$ & Very High & 66 & 33.8 \\
$\mathbf{1 1 4 - 1 3 9}$ & High & 118 & 60.5 \\
$\mathbf{8 8 - 1 1 3}$ & Medium & 11 & 5.64 \\
$\mathbf{6 2 - 8 7}$ & Low & 0 & 0 \\
$\mathbf{3 6 - 6 1}$ & Very Low & 0 & 0 \\
& & $\mathbf{1 9 5}$ & $\mathbf{1 0 0}$ \\
\hline
\end{tabular}

Table 2 shows as much as $33.8 \%$ of students have career planning is very high, 60.5 students have career planning high and $5.64 \%$ of the students have career planning is medium and none at all students who have a career planning low especially very low, Therefore it can be concluded that the overall percentage of students career planning at the high category. Students already have a solid plan about their future and no more students who do not care about their future. This needs to be maintained and even improved for a more mature career planning.

\section{Result and Discussion}

Research Hypothesis Namely: The contributions of Students Perception on Majors toward Student's Career Planning

Contribution analysis results of the students' perception on majors toward student's career planning can be seen in the following table

\begin{tabular}{ccc}
\hline Variables & $\mathbf{R}$ & $\boldsymbol{R}$ Square \\
$\mathbf{X}_{2}-\mathbf{Y}$ & 0580 & 0336 \\
\hline
\end{tabular}

The table shows RSquare of 0336 . This means that $33.6 \%$ of student's perceptions about the level of contribution to the majors in student's career planning.

\section{Discussion}

In this section provides a discussion of each of the variables in this study as follows.

\section{Student's Perceptions on Majors}

Analysis of the research data, that on average, students' perception on occupied majors is in a positive category. Aspects that affect the learning process and career college students are the support of family, psychological factors, learning systems and interest in the subject that occupied (Daharnis \& Ardi in Khan 2016).

Suitability of students to courses that were occupied at this time can be understood that as much as $22.13 \%$ of the students do not get along with the majors they occupy at present, and only about $3.28 \%$ of students feel very good with the department. However, in general, students were matched 
with majors that he occupied as much as $64.75 \%$. The mismatch condition, in fact, has an impact on the condition of students' learning activities (Daharnis \& Ardi 2016).

Student's perceptions have positive on the majors is a process that formed gradually. This relates to students who are majoring occupied, if the student feels uncomfortable or feel constrained. This will affect the continuation of the student's career. Perception is a process which is for individuals to be able to understand the environment by means of selecting, organizing and interpreting information from the environment (Daft 2002). In line with the above opinion Sternberg (2008: 105) "The perception of people about something not only from a mental action, but involves a long process starting from identifying, organizing, to understand the responses received through the senses catch from the surrounding environment".

Students who have a positive perception of the department that is occupied will be motivated, keen to learn and have a mature career planning. The results of the research described earlier that students' perceptions of the majors are in a positive category. Although perceptions of students about the subject have been on the positive category, must be maintained and improved so that students' perceptions about the majors did not have a view that is not good.

\section{Student's Career Planning}

Study data analysis results show the average student's career planning at the high category. It is understandable that students have a good career planning and ripe for their future. This is in line with the results of a study that found that the average career planning at the high category and indicators in planning a career-high this needs to be maintained, because the career planning of high someone will succeed in his career (Latif, Yusuf \& Effendi (2017).

Students are required to maintain and even improve the planning of their careers. in ways that can be done to improve the career planning of students is through information services. this is consistent with the results of research conducted by Rahmaniah (2013) that the service information about his career have influence positively on career planning student, planning a career dogged occur if the student has the ability in terms of understanding oneself, understanding the environment, formulating options, and the formulation of an action plan (Afdal, Surya, Syamsu \& Uman (2014). Furthermore, a person who has a career planning will seek to understand its potential, to understand the environment, the possibility of the career that suits him, then prepare for a career that will be lived later (Latif, Yusuf \& Effendi (2017).

Given an early career planning for students in achieving a successful career, it is expected that students can complete assignments according to the stage of career development (Sulusyawati, Joseph \& Daharnis, 2017).

\section{Contribution Student's Perception on majors toward Student's Career Planning}

The results shows that students' perceptions on majors are contributing significantly to the student's career planning by $33.6 \%$. The discovery was based on a series of the data analysis.

There is contribution perceptions of students about the majors because of the interaction between them. If students have a positive perception of the majors, it can be indicated that the student's career planning tends to be high. Likewise, if students have a negative perception on majors it maked student's career-planning tend to be low anyway. 
Students in determining the direction of career can be said to be in a state of dilemma as it relates to the ability nor the interest in determining her career is still lacking. It is influenced by factors such as internal factors and external factors, one of which is the perception of students about the subject that has been occupied. Furthermore, the ability to understand what really happened on oneself is one important factor in coping with various life activities one of which is in the process of student's career planning (Wijayacipta, Marjohan \& Daharnis, 2014).

It is understandable that there are several factors that can increase student's career planning, one of which is the perception of students.

\section{Conclusion}

Perceptions of students about the majors on average are in a positive category next, career planning is an average student at the high category. But still, need to be followed to maintain and even improve student career planning.

Positive student's perception about the majors contributed significantly to the student's career planning by $33.6 \%$. Positive student's perceptions about the majors will contribute also to the students' career planning. That is, if the students' perception of majors increased to very positive, student's career planning will rise to a higher.

\section{Reference}

Afdal, A., Surya, M., Syamsu, S., \& Uman, U. (2014). Bimbingan Karir Kolaboratif dalam Pemantapan Perencanaan Karir Siswa SMA. Jurnal Konseling dan Pendidikan, 2 (3): 1-7..

Daft, R. L. (2002). Manajemen Edisi Kelima Jilid 1. Jakarta: Erlangga.

Daharnis \& Ardi, Z. (2016). The Compatibility Student Choice of University Majoring; a Preliminary Studies. Guidena Journal.1 (6): 101-109.

Erezka, R. (2012). "Hubungan antara Motivasi Siswa Memilih Sekolah dan Prestasi Belajar terhadap Perencanaan Arah Karier (Studi pada Siswa Kelas XI Sekolah Menengah Atas Kartika 1-5 Padang". Tesis Tidak Diterbitkan. Padang: Program Pascasarjana UNP.

Kemboi, R. J. K., Kindiki, N., \& Misigo, B. (2016).“Relationship between Personality Types and Career Choices of Undergraduate Students: A Case of Moi University, Kenya". Journal of Education and Practice. 3 (7): 102-112.

Khadijah, K., Marjohan., \& Bentri, A. (2016). “Kontribusi Dukungan Orangtua dan Persepsi Siswa tentang Disiplin Belajar terhadap Perilaku Membolos serta Implikasinya terhadap Layanan Bimbingan dan Konseling". Jurnal Konselor. 5 (3): 172-181.

Latif, A., Yusuf, A. M., \& Effendi , Z. M. (2017). "Hubungan Perencanaan Karier dan Efikasi Diri dengan Kesiapan Kerja Mahasiswa". Jurnal Konselor. Padang: Universitas Negeri Padang. 6(1): 29-38

Lwin, T., Aslam, S., \& Mukhela, P. (2017) "International Students Perceptions of Their Learning Environment in Graduate Program at One Normal University in China". Journal of Education and Practice. 9 (8): 229-233.

Putri, D. P., Neviyarni, S., \& Irianto. A. (2015).Efektifitas Layanan Informasi dengan Pendekatan Contextual Teaching and Learning dalam Meningkatkan Arah Perencanaan Karier Siswa SMK.Jurnal Konselor. Padang: Universitas Negeri Padang. 3 (4): 147-161.

Rahmaniah, A. (2013). “ Kontribusi Layanan Informasi dan Layanan Penempatan/ Penyaluran terhadap Perencanaan Karier Siswa". Jurnal Konseling dan Pendidikan. Padang: Universitas Negeri Padang. 1 (3): 43-51 
Sharf, R. S. (2010). Applying Career Development Theory to Counseling. Edition 5 TH Pacific Grove, California. University of Delaware: Brooks/Cole Cengage Learning.

Sternberg, R. J. (2008). Psikologi Kognitif Edisi Keempat. Terjemahan oleh Yudi Santoso. Yogyakarta: Pustaka Pelajar.

Sulusyawati, H., Yusuf \& Daharnis, (2017).Perencanaan Karier Siswa di SMA Ditinjau dari Status Sosial Ekonomi, Jenis Kelamin, dan Jurusan.Jurnal Bikotetik. 1 (1): 0-36

Wijayacipta, A., Marjohan., \& Daharnis. (2014). “Kontribusi Konsep Diri Siswa dan Keterlibatan Orangtua terhadap Pemilihan Sekolah Lanjutan di SMPN 25 Padang". Jurnal Konselor. Padang: Universitas Negeri Padang. 3 (4): 147-157.

Winkel, W. S., \& Hastuti, S. (2013). Bimbingan dan Konseling di Institusi Pendidikan. Yogyakarta: Media Abadi. 